\title{
REVIEW OF SHORT-TERM RENTALS AND THEIR POTENTIAL SOCIAL IMPACT
}

\author{
SELINA ANGEL \& SEDEF DOGANER \\ Department of Architecture, University of Texas at San Antonio, USA
}

\begin{abstract}
This paper reviews the development of short-term rentals (STRs) and discusses their potential social impacts within historic neighborhoods. The paper focuses on cultural heritage tourism, the characteristic of cultural travelers, and emphasizes the importance of community. The growth management of STRs in neighborhoods are also discussed in order to sustain tourism, but prevent displacement. South San Antonio neighborhoods along the San Antonio Missions World Heritage Buffer Zone are selected as a case study. These neighborhoods are originally outside of the tourist bubble but this fact has recently started to change because of the 2015 WHS inscription. The methodology includes review of short-term rentals in the San Antonio neighborhoods and data collection from the Development Services Department on regulated, unregulated, and grandfathered STRs. The findings of this paper will help cities understand the importance of managing STRs and its social impact, and how regulations can help keep the original essence of life in these historic neighborhoods and prevent gentrification.
\end{abstract}

Keywords: cultural heritage tourism, short-term rentals, social impact, historic neighborhoods, gentrification, heritage management, cultural sustainability.

\section{INTRODUCTION}

Short-term rentals (STRs), a residential property that is rented out for a short stay, can be seen popping up everywhere! Some would say that STRs are contributing to a "shared economy", a peer-to-peer distribution of goods and services through community-based exchange. Others would argue that STRs are dramatically changing the social fabric of a community. As new policies are put into place to regulate the STR trend, sustainable development must be the focus of this new practice.

In 2015 San Antonio became the first city in Texas to become a United Nations Educational, Scientific, Cultural Organization (UNESCO) World Heritage Site (WHS). The designation includes five Spanish colonial missions: Mission Espada, Mission San Juan, Mission San Jose, Mission Concepción, and Mission San Antonio de Valero, more commonly known as the Alamo. A World Heritage Buffer Zone, approximately 5,755 acres of surrounding lands, was created to allow, not only for the environmental protection around the San Antonio missions, but also to moderate the impact of future development of the City of San Antonio [1].

The globalization of San Antonio's WHS has caused an increase in visitation, tourist spending and new development. According to a 2018 National Park Service Report [2], there were $1,208,104$ total recreation visits that contributed to $\$ 87,957$ in visitor spending. Short-term rentals have not only intensified near the most popular tourist mission and attraction, The Alamo, but have spread around the other San Antonio missions. The impact on the neighborhoods surrounding the Southern missions may not be as dramatic as the neighborhoods surrounding the Alamo, due to location, but as the level of tourism increases, along with the rise of future development, the amount of STRs will also potentially grow. The paper discusses the potential social impacts of STRs, and analyzes the state of STRs in San Antonio in order to manage its growth. 


\section{CULTURAL HERITAGE TOURISM}

Tourism is one of the economic generators of the industry. As of 2019 , over $10 \%$ of the global GDP comes from travel and tourism, creating more than 300 million jobs worldwide [3]. In the United States alone the tourism industry provides jobs to 15.8 million people, generates an economic output of \$2.6 trillion and \$1.1 trillion in traveler spending [4]. There are many types of reasons why people travel, for leisure, business, religion, family, health, sports, education, or entrainment. However, $40 \%$ of travelers travel for cultural purposes [3]. These types of tourists are called "cultural tourists". Studies have shown that cultural tourists tend to spend more per day (an average of 60\% more than the traditional traveler that travels domestically), stay longer, take more trips annually, are more likely to shop, tend to have higher household incomes, and are most likely to have a post-high school education. Even though many cultural tourists are baby boomers, there has been a growth in the millennial demographic in this market. $73 \%$ of millennials prefer to travel to a destination that is filled with arts and culture, while two-thirds of millennials desire an authentic experience when travelling [5]. In 2018, there was an estimated $47 \%$ of international arrivals of cultural tourists compared to a $16 \%$ of motivation-based tourists. The cultural tourist is "more interested in local customs, traditions, history, and culture of a place. It is no wonder that $84 \%$ of Member States of the World Tourism Organization (UNWTO) put emphasis in marketing and promoting cultural tourism" [6].

Cultural heritage tourism has numerous economic benefits such as the creation of new jobs and businesses. This stimulates the economy both directly and indirectly, causing a multiplier effect [7]. However, benefits of cultural heritage tourism extend beyond economics. The preservation of heritage within a community can lead to an enrichment of society by giving the place an identity. By honoring the roots and origins of a place, a link with the past is formed, allowing the modern-day residents to understand the present [8]. Heritage sites provide "real-world classrooms where both children and adults - local and visitors - can learn about the history, nature and/or culture of an area. Beyond these opportunities for education regarding the site or wider vicinity, lies the additional potential for increased awareness and understanding of resource preservation" [9].

For heritage tourism to exist, grow and prosper, there must be a cultural heritage within a place. However, the increase in the tourism economy can impose negative effects on a region. Displacement can occur when businesses and the real estate market take over tourist markets. Heritage tourism can disrupt local inhabitants and their quality of life, leading to gentrification, and the loss of identity [8]. This is the reason why there must be a balance between the promotion and protection of a place.

Over time, the accommodation industry has evolved to keep up with the different types of tourism and the changing needs of society. Hotels are no longer alone in the business. The emergence of short-term rentals (STRs) has almost taken over.

\section{SHORT-TERM RENTALS}

The earliest record of STRs can be traced back to the mid-1600s. They were known as vacation homes. The first property: Louis XIV's Palace of Versailles. It was built as a hunting lodge and became a destination for entertainment to political members of its era [10]. By the 1800 s the first timeshares came to be in Europe. Families purchased homes to share throughout the year for vacationing, visiting at different times of the seasons. The invention of the telegraph in 1837 made it easier for renters to request a vacation home. By the 1950s the United States began to list vacation rentals in local newspapers [11]. Vacation rentals became hugely popular in the United States that the creation of the Vacation Rental Management Association (VRMA) was formed in 1985 in order to provide homeowners 
services in housekeeping, reservations, maintenance, marketing, accounting and other services [12]. As the internet was discovered, VBRO (Vacation Rentals by Owner) was the first online platform, launching in 1995. An online marketplace was born. Booking.com emerged one-year later, comparing hotel rates and Craigslist began ads for long- and shortterm rentals around the same time [13]. In 2005, HomeAway purchased VBRO and five different online platforms, merging all inventories into one. But, it was not until 2008 that Airbnb stepped into the race to become one of the world's largest online marketplaces [11]. Within one year of its launch, Airbnb had 2,500 listings and approximately 10,000 members [14]. As of February 2020, Airbnb has 6 million plus listings across the globe, and 150 million plus users. According to iProperty Management, over 2 million people stay in an Airbnb per night [15].

Although, as stated above, there are many other STR platforms, Airbnb will be the focus of this study, due to its popularity, rapid growth, and success in the STR market.

\subsection{Short-term rentals versus hotel chains}

Before the emergence of STRs, staying with family or staying in a hotel was the traditional way to travel and explore places. These are still options today. Reasons why people prefer a hotel over a STR include the various amenities that come with a hotel stay such as room service, concierge services, shuttle transportation, location, kid friendly, business friendly, security, rewards and loyalty programs, brand recognition, free breakfast, a pampered experience and quick, attentive services that are a phone call away. As of 2019, there are over 700,000 hotels and 4 million plus hotel rooms worldwide [16]. Even with the addition of STRs in the market, hotels are still leading the accommodation industry, but that could soon change. According to Fig. 1 from Second Measure, compared to corporate hotel chains, Airbnb is experiencing faster growth at a high rate [17].

STRs, like Airbnb, are a global phenomenon and a market that grows practically every single day. Guttentag [18], the Director of the Department's Office of Tourism Analysis and an Assistant Professor in Hospitality and Tourism Management at the College of Charleston,

\section{Airbnb - U.S. Sales against Industry Competitors}

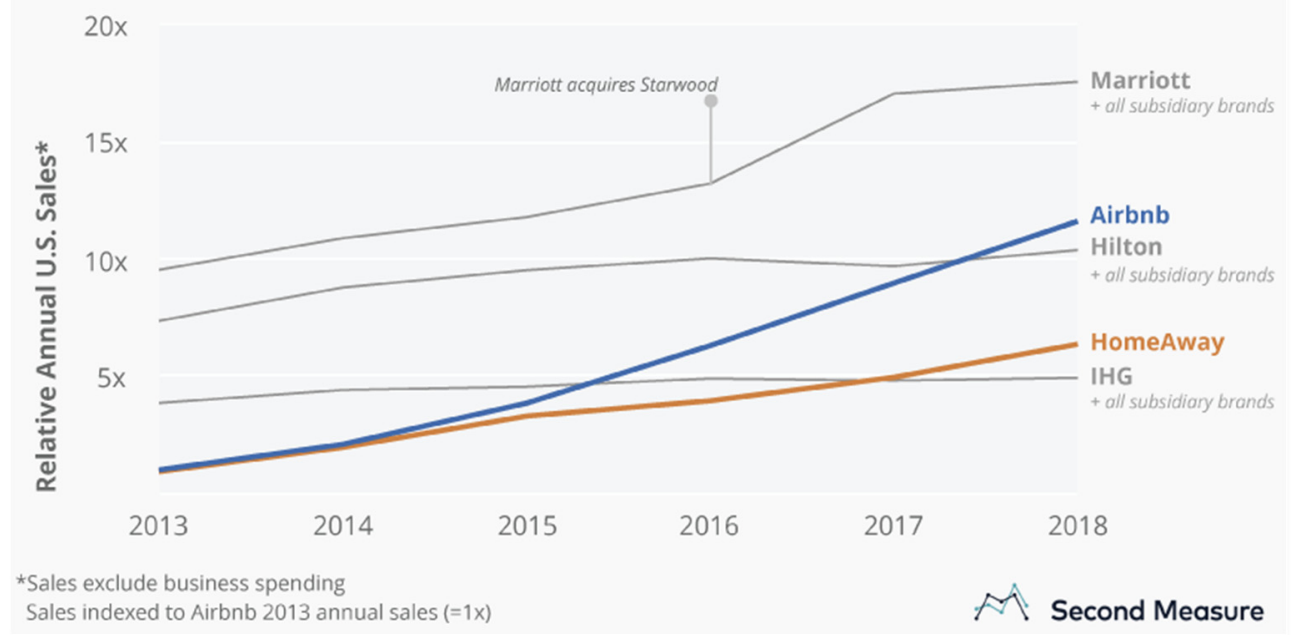

Figure 1: Airbnb: U.S. sales against industry competitors [17]. 
stated: "This rise is examined through the lens of disruptive innovation theory, which describes how products that lack in traditionally favored attributes but offer alternative benefits can, over time, transform a market and capture mainstream consumers".

What do hotels lack that STRs provide? It is not really a lack of attributes but what the consumer is willing to sacrifice. STRs are usually cheaper than a hotel because hotel amenities are not provided. There is no uniformity, predictability, or consistency in STRs, therefore there is no guarantee if a STR will live up to photos or descriptions that are provided through the online platform. Customer service may be slow or non-existent. Before recent laws, STRs were not regulated and many were against building and fire codes. Some STRs are "shared" spaces, where a bathroom, living room and kitchen may be shared with the person that resides in the house or other guests. In a "shared" space, the bedroom is the only space that is considered "personal" space but may lack a lock on the bedroom door. The location is not often central to places of attraction, but in nearby residential areas. Transportation may be necessary to get around but is not provided by the owner of the STR. Despite these downfalls, STRs are still on the rise. The alternative benefits of STRs strongly outweigh the sacrifices made.

According to iProperty Management, approximately $\$ 450$ million in direct revenue is lost from the hotel industry to Airbnb alone [15]. Although, most of the time, it may be cheaper to stay in a STR, this revolution of modern-day travel comes with a price.

\subsection{Short-term rentals and their social impacts}

People who choose STRs over hotels often do because of the local experience. In fact, Airbnb's CEO and co-founder, Brian Chesky, when interviewed on multiple occasions, stated numerous times that "the number one reason people [choose] to travel on Airbnb is [that] they want to live like a local" [19]. The new tagline from Airbnb, "Belong Anywhere" has reflected the creation of new markets of real estate in areas that are outside the tourist bubble, settling in well-established neighborhoods.

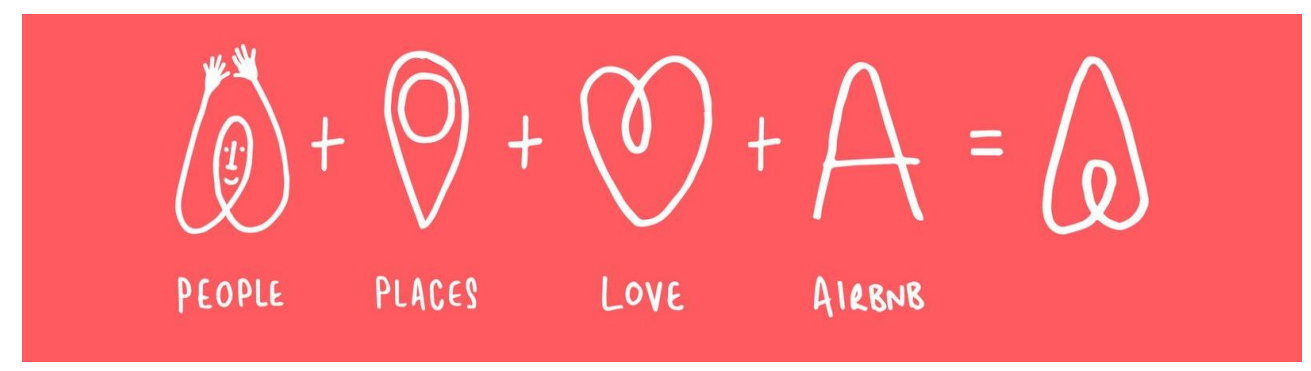

Figure 2: Airbnb's icon development graphic [19].

The consequences of STRs rapid increase outside tourist locations has recently been recognized. There is a lack of restriction. There is a lack of care. There is a lack of sustainability. Many would say that STRs have revitalized neighborhoods while others argue that STRs are leading to the displacement of long-term residents. As the demand for tourism continues to rise, new destinations will emerge, and travel will expand.

Regarding STRs, there are three major impacts STRs have on communities when it comes to achieving sustainability: economic, environmental, and social. This paper will only discuss the social impact of STRs. 


\title{
3.2.1 Social impact
}

Travelers want an authentic insight of the city they travel to. STRs provide that with shared accommodation that is embedded within a community. Guests are immersed in the local context. $86 \%$ of guests who used Airbnb's have stated that the location was convenient and $77 \%$ of Airbnb guests chose the STR because they wanted to live like a local [20]. Travelers look to explore areas outside the beaten path and interact with locals to understand and educate themselves with the culture, historic heritage, everyday lifestyles, and traditions of a city. They want to know the secrets and the hidden gems of an area. They want to experience a meaningful connection to the city.

\begin{abstract}
"Authenticity is anchored in society. Normal daily life cannot be considered authentic because it is not unique (every day the same...), but there is an argument that asserts that everything a tourist experiences as authentic must be considered as such. The discussion does not stop there. One has to realize all the time that what may be authentic in the eyes of a tourist may be daily routine for a local. The opposite holds true, too: things that local people feel are special and authentic in their society may be ignored completely by tourists" [21].
\end{abstract}

The rise of STRs in residential districts is taking away the sense of a neighborhood. Houses remain vacant until the tourists arrive for the weekend. Neighbors are now strangers and change every week. A study showed that out of 6,508 Airbnb's in New Orleans $85 \%$ were owned by San Francisco and New York City investors. There is a loss of autonomy in the area and a loss of identity. Communities are becoming commodities. Everyday life becomes difficult for residents because the neighborhood becomes a theme park for tourists or on the other side of the spectrum ghost towns. STRs take "away the soul of [a] place and the social tissue that make[s the] place alive" [22]. There becomes a dislike for tourists in the neighborhood. There is frustration due to the lack of regulation and implementation from local authorities. People start moving away. Without these long-term residents, there is no true neighborhood. There is no longer authenticity.

\subsubsection{Gentrification}

STRs fuel gentrification and displacement in four ways described in a report by the Jane Place Neighborhood Sustainability Initiative [23]:

- With the prioritization of tourists over residents.

- The oversaturation of STRs in residential neighborhoods.

- Single operators with multiple listings.

- Spillover effects from the monetization of residential housing inflating overall costs for renters and homeowners.

When tourism generates a wealthy economy, public, private, and non-profit entities seem to focus their attention on tourists rather than residents. There is a priority for projects in tourist districts to beautify the area to be more presentable to travelers. This attracts developers to invest in the area. The same thing happens when STRs take over a neighborhood. Investors buy into the neighborhood. Even existing landlords will throw out long time renters to accommodate short-term renters because replacing long-term tenants with short-term visitors is more profitable. In Austin, Texas homeowners are charging almost six times the price of the local rent for an Airbnb and travelers are paying for it [24].

It is because of this "authentic atmosphere" tourists pay the price. The authenticity of the neighborhood was first driven by the lack of tourists in the area. The "edgy" part of town which are the "transitional neighborhoods or zones where people are on the margins of urban 
society", areas where the natural habitat of locals reside [25]. These places are often of a low income and minority demographic; the reason why it is so easy for investors to buy into the cheap real estate market that is sparking new urban tourism. "Compared to the traditional rental market, short-term rentals offer a number of benefits that enhance market efficiency for property owners, making them increasingly attractive for both local and global investors" [26].

These investors usually do not care about the authenticity of a place, yet alone the people that reside in the neighborhood. In fact, less than $20 \%$ of Airbnb's are true home-sharing residencies, where the homeowner is present [27]. That means that more than $80 \%$ of Airbnb hosts are not associated with the community in which they rent out and most likely have the STR as a side business. In return, this potentially causes problems for locals to find affordable long-term housing. "More houses, apartments and condos available on home-sharing platforms translates into fewer options for those who live [in the area] full time" [28]. The supply in the traditional private market is becoming less available, "provoking exclusionary displacement as new residents are unable to move in. The result is a tacit change in land use from residential to tourist uses that residents experience as a process of social injustice" [26].

\section{ANALYSIS SHORT-TERM RENTALS IN SAN ANTONIO, TX}

In 2018 San Antonio was listed as one of the world's 50 best places to travel in the Travel+Leisure magazine, making it only one of three U.S. cities [29]. San Antonio brings in about 37 million visitors a year, supports approximately 140,188 jobs, and collects $\$ 15.2$ billion for the local economy annually [30]. As of 2016, there were 35,000 hotel rooms in San Antonio. Of those 13,500 of them were in the downtown area [31]. In the third quarter of 2017, there were more than 2,000 active listings, making San Antonio the fourth highestgrossing city in Texas for Airbnb rentals [32].

Hotels give back to their communities by paying an average of $\$ 186$ billion in local, state, and federal annual taxes combined in the U.S [33]. In San Antonio, the Hotel Occupancy Tax (HOT) revenue goes to support convention activities, public improvements, tourism, art and cultural programming for the city [34]. Up until 1 May 2017, a HOT was not collected from Airbnb's in Texas. In 2016, this resulted in an estimated \$8 million HOT loss from Airbnb's in San Antonio alone [32]. Now that cities are starting to regulate STRs, there has been a decrease in Airbnb's.

\subsection{Short-term rental regulations}

In order to sustain tourism and prevent displacement, on 1 November 2018, San Antonio's City Council passed an ordinance establishing regulations over STRs, which included "the protection of the health and safety of occupant(s) of short-term rental properties, and to protect the integrity of the neighborhoods in which short-term rental properties operate" [35]. The city defines a STR as a "residential dwelling unit, apartment, condominium or accessory dwelling where sleeping areas are rented to overnight guests for a period of less than 30 consecutive days (but not less than 12 hours)" [36]. Under the ordinance STRs must apply for a permit with the COSA Development Services Department (DSD) in order to legally operate within San Antonio city limits. There are two types of permits:

1. Type 1 - The primary residence of the operator or owner; allowed anywhere if the operator or owner resides on the property.

2. Type 2 - The operator or owner does not occupy the residence; must follow density rules. 
Density limitations are only for Type 2 STRS which can only be $12.5 \%$ of block-face in a residential area, by right, and in a multi-family housing unit can also only have no more than $12.5 \%$ of the total number of units be STRs, by right. Only the Board of Adjustments may allow the $12.5 \%$ density to be exceeded [37].

\subsection{Short-term rentals in the south}

Even though STRs are dense in the heart of downtown, this study focuses on an area south of downtown along the UNESCO San Antonio Missions World Heritage Buffer Zone (WHBZ). The zone consists of many neighborhood associations such as the Downtown Residents Association, King William, Lavaca, Lone Star, Roosevelt Park, Mission San Jose, Hot Wells Mission Reach, and Villa Coronado. Although each association and neighborhood are unique, all were created to preserve, protect, and sustain each community character. The Downtown Residents Association was created in 1982 and strives for a live work and play vibe [38]. King William's Association was created in 1967 and is mainly a neighborhood of Victorian homes built for prosperous German families after the Civil War [39]. Lavaca has a diverse culture that is highly active within the community. It is the oldest neighborhood in San Antonio [40]. The Lone Star Neighborhood Association is one the newest organizations in the city, founded in 2013, and is known for the artistic culture within their neighborhood [41]. Roosevelt Park Neighborhood Association was established in 1978 and main mission is to enhance the quality of life and create a safe environment within their neighborhood [42]. Mission San Jose Neighborhood Association was established in 1995 and consists of residents that are descendants of the laborers of Mission San Jose.

Aside from the Downtown Residents Association, King William, and Lavaca, the other neighborhoods in the WHBZ are predominately of a minority and lower income demographic, a reason why these neighborhoods are vulnerable to an increase in STRs. These "edgy" neighborhoods are trending because of the realness and authentic experience they provide and their strong intangible heritage.

In order to visualize the growth of STRs, current data were collected from City of San Antonio's (COSA) Development Services, and merged with shapefiles downloaded from the COSA GIS website. The study area was broken down into the closest geographical spatial data to the WHBZ, zip codes: 78204, 78210, 78214, and 78223. The WHBZ and these zip codes can be seen in Fig. 3, along with the number of short-term rentals within these zip codes. The ordinance has only been in full effect since February 2019. Only 519 STRs were grandfathered in, as of 11 April 2019. The city believes that there are about 1,500-2,000 properties that are not operating legally [43]. From the data provided by the City of San Antonio's Development Services Department, it was found that there is a total of 375 STRs in San Antonio, that the city is aware of, as of 24 February 2020. This includes grandfathered, non-compliant and registered STR properties.

Zip code 78210 consists of $63 \%$ of known STRs in San Antonio (236 properties). Out of these 236 properties, 146 are registered with the city and 76 properties have been grandfathered into the system. This means that approximately $6 \%$ of STRs in the 78210 zip code are non-compliant. Zip code 78204 has the second highest number of STRs with 112 properties, with 87 properties registered with the city, 13 grandfathered and 12 noncompliant.

Zip codes 78210 and 78204 are located nearest San Antonio's downtown core. The largest clusters reside furthest North of the study area which then trickle off alongside of the highways and South near the WHBZ boundary. Zip code 78223 is the zip code that stretches 


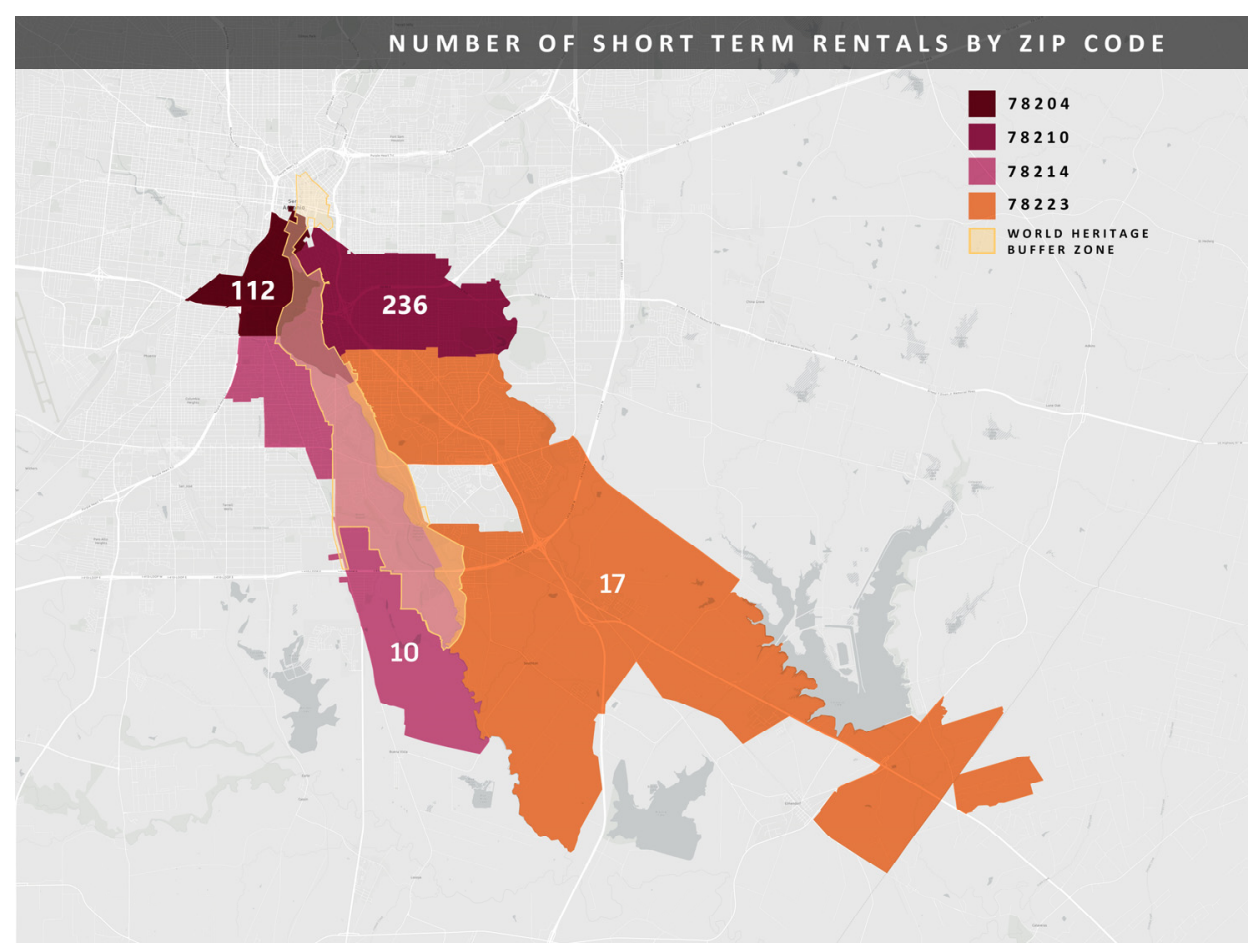

Figure 3: Short-term rentals by zip code as of 24 February 2020. Data sourced from City of San Antonio's Development Services Department. Chart created 30 April 2020 by Selina Angel.

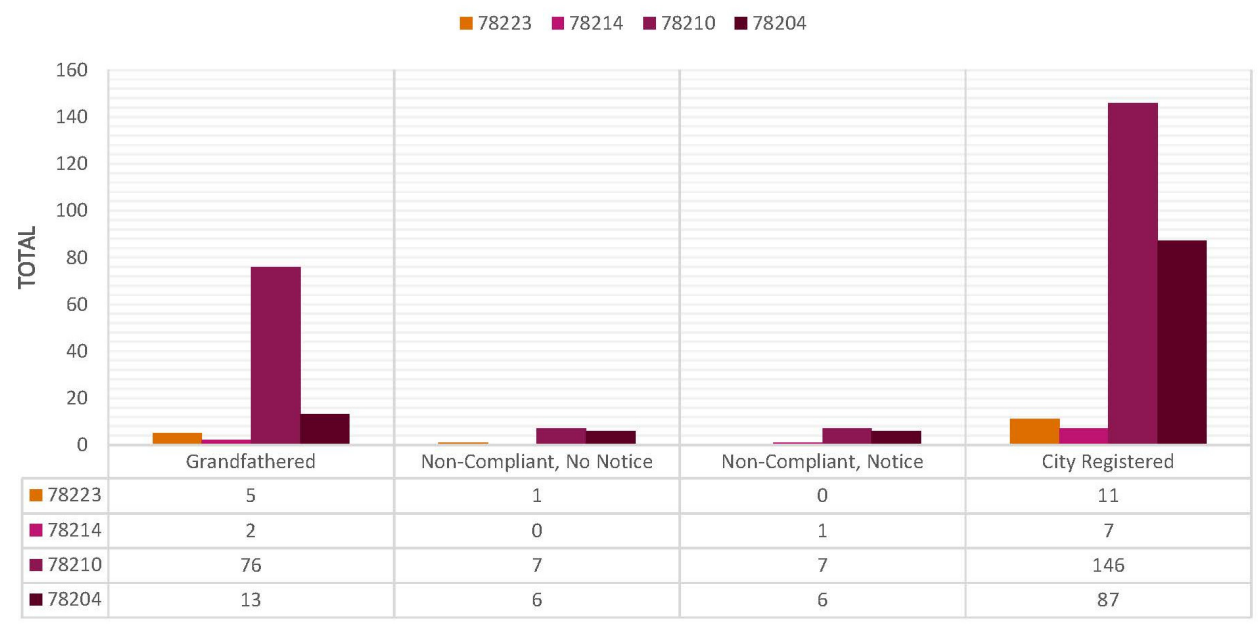

Figure 4: Short-term rental status as of 24 February 2020. Data sourced from City of San Antonio's Development Services Department. Chart created 30 April 2020 by Selina Angel. 
furthest South but does not have the least amount of STRs. It is the 78214 zip code that has the least amount, at a total of 10 properties (seven registered with the city, two grandfathered and one non-compliant), however the 78214 STRs still follow along the WHBZ boundary while the 78223 STRs are seen furthest away from the WHBZ boundary (Figs 3 and 4).

\section{CONCLUSION}

There is an increase in development amongst the neighborhoods that encompass the San Antonio Missions leading to an increase of STRs in these well-established but quite vulnerable neighborhoods. In this case, STRs may not have had a significant impact on the social fabric of a community yet, however we know the housing market is drastically changing. For it is the unique, distinct character of place that brings STRs into existence, but it is also that same element of heritage and irreplaceable identity that must be protected. Fortunately, San Antonio has put in place regulations and is implementing STRs policies, which may help communities, stay intact, and residents not gentrified not only within in the World Heritage Buffer Zone but also the surrounding areas. This way, "shared economy" with STRs can be sustained while controlling the growth, and still preserving the history and identity of neighborhoods. Since this research was done at a time, where regulations were fresh, as time passes more information on STRs will be readily available. Additionally, future studies will have a greater amount of information and can determine if the regulations have caused a plateau in STRs or has caused an overall disappearance.

As previously mentioned, the social impacts of STRs take away the sense of a neighborhood. Communities become commodities and everyday life becomes difficult for residents because the neighborhood becomes a theme park for tourists or on the other side of the spectrum ghost towns. These negative social impacts may have been avoided with the help of new STR regulations, but further demographic and housing market studies should be also be completed in order to fully understand if there are any significant correlations between these three variables. All of these data may also drastically change after COVIT19 pandemic in 2020, and the change in both tourist demand and residents' response should be analyzed in the future.

\section{REFERENCES}

[1] City of San Antonio (COSA), World Heritage Zone Neighborhood, Community And Sector Plan Update, 30 pp., 2016. www.sanantonio.gov/Portals/0/Files/ WorldHeritage/WorkPlanUpdates/LandUse/ENGLISH\%202016\%20WHBZ\%20City \%20Approved\%20Land\%20Use.pdf?ver $=2018-02-05-101757-203$. Accessed on: 30 Jan. 2020.

[2] National Park Service, 2018 National Park Visitor Spending Effects, National Resource Stewardship and Science: Fort Collins, CO, 57 pp., 2019.

[3] Hosking, N., Why we all need to travel with purpose, Global Heritage Fund, 2019. https://globalheritagefund.org/2019/09/27/why-we-all-need-to-travel-with-purpose/.

[4] U.S. Travel Association, U.S. travel answer sheet, 2019. www.ustravel.org/ answersheet. Accessed on: 3 Feb. 2020.

[5] Payne, J., Insider exclusive: Heritage tourism - Facts and figures, American Bus Association, 2018. www.buses.org/news/article/insider-exclusive-heritage-toursimfacts-figures. Accessed on: 4 Feb. 2020.

[6] World Tourism Organization, Tourism and Culture Synergies, The (UNWTO), 2018. www.e-unwto.org/doi/pdf/10.18111/9789284418978. Accessed on: 4 Feb. 2020.

[7] Barcelona Field Studies Centre S. L., Tourism multiplier effect, 2020. https://geographyfieldwork.com/TouristMultiplier.htm. Accessed on: 9 Feb. 2020. 
[8] Doganer, S. \& Dupont, W., Accelerating cultural heritage tourism in San Antonio: A community-based tourism development proposal for the Missions Historic District. International Journal of Sustainable Development Planning, 10(1), pp. 1-19, 2015.

[9] Jun, S.H., Nicholls, S. \& Vogt, C., Heeding the call for heritage tourism: more visitors want an "experience" in their vacations: something a historical park can provide, 2004. http://citeseerx.ist.psu.edu/viewdoc/download?doi=10.1.1.602.6461\&rep=rep1\&type $=$ pdf.

[10] Martinelli, K., Everything you need to know about the vacation rental industry, Part 1, 2020. www.futurestay.com/read/vacation-rental-history/vacation-rental-industry/.

[11] Akande, I., The history of vacation rentals: Infographic, 2015. https://rentalsunited.com/blog/history-of-vacation-rentals-infographic/. Accessed on: 11 Feb. 2020.

[12] VRM Intel Staff, Measuring performance for vacation rental management companies, 2013. Www.vrmintel.com/part-one-a-look-back-at-how-the-marketing-andcompetitive-landscape-has-changed-for-vacation-rental-managers/. Accessed on: 16 Feb. 2020.

[13] KeyCafe, The history of short-term rentals, 2020. https://blog.keycafe.com/thehistory-of-short-term-rentals/. Accessed on: 18 Feb. 2020.

[14] Jasper, The Airbnb founder story: From selling cereals to a \$25B company, 2019. https://getpaidforyourpad.com/blog/the-airbnb-founder-story/. Accessed on: 18 Feb. 2020.

[15] iProperty Management, Airbnb statistics, 2020. https://ipropertymanagement.com/ research/airbnb-statistics. Accessed on: 22 Feb. 2020.

[16] Condor Ferries Ltd., Top hotel statistics, 2000. www.condorferries.co.uk/hotelindustry-statistics. Accessed on: 24 Feb. 2020.

[17] Gessner, K., Ahead of IPO, Airbnb's consumer sales surpass most hotel brands, Second measure, 2019. https://secondmeasure.com/datapoints/airbnb-sales-surpassmost-hotel-brands/.

[18] Guttentag, D., Airbnb: Disruptive innovation and the rise of an informal tourism accommodation sector. Journal of Current Issues, 18(12), pp. 119-1217, 2013.

[19] @Silver86, Airbnb's brand evolution, 2016. https://all-about-airbnb.com/ post/143221488726/airbnb-brand-evolution-live-there. Accessed on: 25 Feb. 2020.

[20] Airbnb, New data: The Airbnb advantage, 2019. https://news.airbnb.com/new-datathe-airbnb-advantage/. Accessed on: 4 Apr. 2020.

[21] Gisolf, M., The background of sustainable tourism, 2010. www.tourismtheories.org/ ?p=958. Accessed on: 6 Apr. 2020.

[22] Wisniewska, A., Are Airbnb investors destroying Europe's cultural capitals? Financial Times, 2019. www.ft.com/content/2fe06a7c-cb2a-11e9-af46-b09e8bfe60c0.

[23] Jane Place Neighborhood Sustainability Initiative, Short-term rentals, long-term impacts: The corrosion of housing access and affordability in New Orleans. https://storage.googleapis.com/wzukusers/user27881231/documents/5b06c0e681950 W9RSePR/STR\%20Long-Term\%20Impacts\%20JPNSI_4-6-18.pdf.

[24] Geier, B., Where investors are taking advantage of Airbnb 2019, CEPF, 2019. https://smartasset.com/financial-advisor/where-investors-are-taking-advantage-ofshort-term-rental-market-2019. Accessed on: 8 Apr. 2020.

[25] Judd, D.R., Visitors and the spatial ecology of the city. Cities and Visitors: Regulating People, Markets and City Space, eds L.M. Hoffman, S.S. Fainstein \& D.R. Judd, Blackwell Publishing, pp. 23-38, 2003.

https://onlinelibrary.wiley.com/doi/10.1002/9780470773673.ch. 
[26] Cocola-Grant, A. \& Gago, A., Airbnb, buy-to-let investment and tourism-driven displacement: A case study in Lisbon. Environment and Planning A: Economy and Space, pp. 1-18, 2019.

[27] CBRE, Hosts with multiple units: a key driver of airbnb growth. a comprehensive national review including a spotlight on 13 U.S. markets, 2017. www.ahla.com/sites/ default/files/CBRE_AirbnbStudy_2017_0.pdf.

[28] Dolven, T., Hanks, D. \& Gurney, K., Why Airbnb is making it harder for Miami locals to find a place to rent, 2019. www.miamiherald.com/news/business/tourism-cruises/ article231476068.html. Accessed on: 9 Apr. 2020.

[29] Egan, J., Alamo City crowned World's top tourist destination for 2018 once again, Culturemap San Antonio, 2017. https://sanantonio.culturemap.com/news/city-life/1211-17-travel-leisure-magazine-touts-san-antonio-worlds-top-travel-destinations-for2018/. Accessed on: 9 Apr. 2020.

[30] Visit San Antonio, Celebrate national travel and tourism week: May 5-11, 2019, 2019. www.visitsanantonio.com/nttw/. Accessed on: 13 Apr. 2020.

[31] Rivard, R., Getting real with the San Antonio visitor economy, 2016. https://therivardreport.com/getting-real-san-antonio-visitor-economy/. Accessed on: 13 Apr. 2020.

[32] Dimmick, I., Short-term rentals debate to continue at City Hall, State Lege. The Rivard Report, 2017. https://therivardreport.com/short-term-rentals-debate-to-continue-atcity-hall-state-lege/. Accessed on: 27 Mar. 2020.

[33] Oxford Economics, Economic impact of the US hotel industry, 2019. www.ahla.com/ sites/default/files/oxford2019.pdf. Accessed on: 23 Mar. 2020.

[34] City of San Antonio, Hotel occupancy taxes, 2000-2020. www.sanantonio.gov/ Finance/about/faq. Accessed on: 20 Mar. 2020.

[35] City of San Antonio, November 1. Article XXII. Short-term rentals division I: general, 2018. https://docsonline.sanantonio.gov/DSDUploads/STROrdinanceAsPassed.pdf. Accessed on: 14 Apr. 2020.

[36] City of San Antonio, Short-term rentals ordinance fact sheet, 2019. https://docsonline.sanantonio.gov/DSDUploads/STRFactSheet.pdf. Accessed on: 16 Apr. 2020.

[37] City of San Antonio, Indoor notification template, 2019. https://docsonline.sanantonio.gov/DSDUploads/STRIndoorNotificationTemplate.pdf. Accessed on: 19 Apr. 2020.

[38] Meyer, C., DRA annual activities March 2008-March 2009. www.neighborhoodlink.com/Downtown/info. Accessed on: 27 Apr. 2020.

[39] King William Association, Who we are, 2020. www.kwfair.org/p/about/147. Accessed on: 27 Apr. 2020.

[40] Lavaca Neighborhood Association, Welcome to Lavaca! 2011. http://www.lavaca.net/. Accessed on: 28 Apr. 2020.

[41] Southtown the Arts District, About District Mission, 2018. https://southtownsatx.com/about/. Accessed on: 28 Apr. 2020.

[42] Roosevelt Park Neighborhood Association, Inspiring a neighborhood, 2020. www.rooseveltparkna.org/about/. Accessed on: 28 Apr. 2020.

[43] Alley, L.T. \& Rivers, R.D., Short-term rental study 2019, ed. City of New Orleans, City Planning Commission, 2019. www.nola.gov/nola/media/City-Planning/Final2019-STR-Study-with-Maps.pdf. Accessed on: 23 Apr. 2020. 